\title{
PENINGKATAN HASIL BELAJAR EKONOMI MELALUI METODE EKSPOSITORI PADA SISWA KELAS XI IPS 3 SMAN 1 KOTO BALINGKA
}

\author{
Desmawati \\ Guru Pendidikan Ekonomi pada Sekolah Menengah Negeri 1 Koto Balingka, \\ Pasaman Barat; Email: desma_wati@gmail.com
}

\begin{abstract}
The purpose of this study was to improve student learning outcomes in economic subjects through expository learning methods in students of class XI IPS 3 SMA Negeri 1 Koto Balingka in the school year of 2015/2016. This study was conducted through classroom action research. Data in this study were collected through several techniques that are (1) observation, (2) documentation, (3) cycle final test. Data were analyzed by using analysis of class score average, classical learning completeness, student activity observation, and questionnaire on student responses. The results of this study indicated that there is an increase in student learning outcomes before and after the action at the end of the first cycle with the average scores and percentage of learning mastery that increased from cycle I to cycle II, that is from the average score of 71.9 to 83.3 with the score of minimum mastery criteria (KKM) of 76. Thus it could be concluded that economic learning through expository learning method could improve student learning outcomes in class XI IPS 3 SMA Negeri 1 Koto Balingka.
\end{abstract}

Keywords: Learning outcomes, economic education, expository method

\section{Pendahuluan}

Pendidikan memegang peranan yang sangat penting dalam perkembangan Ilmu Pengetahuan dan Teknologi, karena pendidikan merupakan wahana untuk meningkatkan dan mengembangkan Sumber Daya Manusia (SDM). Guna menghasilkan SDM yang berkualitas diperlukan mutu pendidikan yang baik.

Sebagai seorang guru. peneliti merupakan orang yang bertanggung jawab dalam merumuskan tujuan instruksional yaitu tujuan yang menggambarkan pengetahuan, kemampuan, ketrampilan dan sikap yang harus dimiliki oleh siswa sebagai akibat dari hasil pembelajaran yang dinyatakan dalam bentuk tingkah laku (behavior) yang dapat diamati dan diukur. Peneliti dalam proses pembelajaran sedapat mungkin menciptakan keadaan yang dapat menjadikan siswa sebagai subyek belajar berkembang ke arah positif. Penciptaan keadaan ini dapat menunjang terselenggaranya proses pembelajaran yang efektif.

Berdasarkan hasil pengamatan peneliti di SMA Negeri 1 Koto Balingka, tentang implementasi metode pembelajaran yang dilaksanakan oleh peneliti pada mata pelajaran ekonomi kurang mengarahkan siswa ke arah pembelajaran berpusat pada siswa (student centered learning), diantaranya yaitu pembelajaran yang disampaikan peneliti masih bersifat verbalistik (hafalan) dan penjelasan 
suatu konsep lebih banyak dilakukan secara lisan dan tertulis, sehingga peran aktif siswa dalam proses pembelajaran kurang diperhatikan. Konsekuensi negatif dari kondisi tersebut dapat dilihat dengan kurangnya siswa untuk mengetahui, memahami dan mengaplikasikan konsep terutama pada mata pelajaran ekonomi pada umumnya. Metode pembelajaran yang diterapkan peneliti masih berorientasi teacher centered, artinya peneliti memegang peranan penuh dalam proses belajar mengajar sementara siswa hanya duduk diam menerima pelajaran secara pasif.

Selain itu sistem penyampaian materi pelajaran lebih banyak didominasi oleh peneliti yang cenderung bersikap otoriter, instruktif serta komunikasi satu arah. Metode yang berorientasi teacher centered ini juga dikenal sebagai metode pembelajaran klasikal. Metode pembelajaran ini biasanya dilakukan oleh pengajar dengan berceramah di kelas. Menurut Sagala (2010) "belajar secara klasikal cenderung menempatkan siswa dalam posisi pasif, sebagai penerima bahan ajaran". Metode pembelajaran ini kurang menarik bagi siswa sehingga siswa tidak mempunyai ketertarikan dalam menerima pelajaran yang diajarkan. Metode ini mempunyai kelemahan, yaitu: siswa sering merasa jenuh karena proses belajar mengajar terkesan datar yang mengakibatkan siswa tidur di dalam kelas, siswa berbicara sendiri, atau siswa bermain handphone sendiri di dalam kelas. Hal ini akan mengakibatkan minat belajar siswa akan cenderung turun sehingga hasil belajar menjadi rendah.

Pada saat menghadapi ulangan harian mata pelajaran ekonomi, masih banyak siswa yang belum mampu mencapai kriteria ketuntasan minimum (KKM), Hal tersebut dapat ditunjukkan dengan nilai rata-rata mata pelajaran ekonomi kelas XI yang banyak masih dibawah KKM yaitu 76, kurang maksimalnya nilai siswa tersebut dikarenakan siswa kurang aktif ketika proses pembelajaran di kelas berlangsung dan metode pembelajaran yang cenderung kurang melibatkan siswa atau sistem pembelajaran satu arah, siswa rata-rata tidak fokus saat pelajaran berlangsung, misalnya adanya siswa yang mengantuk, melamun bahkan ada yang asik berbicara dengan teman sebangku.

Sebenarnya sudah dibentuk kelompok belajar tetapi belum berjalan secara efektif karena tidak terjadi pemerataan dalam kelompok tersebut, anggota kelompok yang kurang aktif menggantungkan jawaban dari temannya yang dianggap pintar. Hal ini berpengaruh terhadap hasil belajar siswa baik siswa yang aktif maupun yang pasif. Kondisi siswa yang demikian tersebut, dalam mata pelajaran ini harus dilakukan suatu tindakan khusus berupa ketepatan metode pembelajaran yang menarik siswa dalam kegiatan belajar mengajar agar siswa lebih menguasai materi ataupun kompetensi yang diajarkan. Bila permasalahan hasil belajar yang rendah tidak segera dipecahkan maka akan berdampak negatif terhadap tujuan pendidikan yang pada gilirannya akan menurunkan kualitas pendidikan.

Oleh karena itu, penelitian tindakan kelas ini sangat penting untuk segera diaplikasikan karena dengan proses pembelajaran yang baik diharapkan akan dapat memperbaiki kualitas pendidikan. Salah satu cara untuk mengatasi agar siswa tidak jenuh dan untuk mengembangkan kemampuan siswa yaitu dengan pembelajaran salah satu metode, yaitu metode pembelajaran ekspositori. Dengan diterapkannya metode pembelajaran ekspositori ini, memungkinkan keterlibatan 
setiap siswa sebagai anggota kelompok dalam usaha pencapaian tujuan. Dengan adanya kerjasama demikian, diharapkan dengan menggunakan metode ekspositori ini dapat meningkatkan hasil belajar siswa pada mata pelajaran ekonomi kelas XI IPS 3 SMA Negeri 1 Koto Balingka.

Berdasarkan identifikasi masalah dalam enelitian ini, maka peneliti merumuskan masalah sebagai berikut: "Apakah penggunaan metode ekspositori dapat meningkatkan hasil belajar siswa pada mata pelajaran ekonomi siswa kelas XI IPS 3 SMA Negeri 1 Koto Balingka tahun pelajaran 2015/2016? Penelitian ini bertujuan untuk mengetahui seberapa besar peningkatan hasil belajar siswa pada mata pelajaran ekonomi siswa kelas XI IPS 3 SMA Negeri 1 Koto Balingka dengan menggunakan metode ekspositori.

\section{Tinjauan Kepustakaan}

\section{Belajar dan Perangkat Pembelajaran}

Belajar sering didefinisikan sebagai perubahan yang secara relatif berlangsung lama pada masa berikutnya yang diperoleh kemudian dari pengalamanpengalaman. Disamping itu ada pula sebagian orang memandang belajar adalah semata-semata mengumpulkan fakta-fakta yang tersaji dalam bentuk informasi atau materi pelajaran, latihan membaca dan menulis. Berdasarkan persepsi semacam ini, biasanya mereka akan merasa cukup puas bila anak-anak mereka telah mampu memperlihatkan keterampilan jasmaniah, walaupun tanpa pengetahuan mengenai arti hakikat dan tujuan keterampilan tersebut.

Jika kita renungkan sesungguhnya belajar adalah merupakan kegiatan yang berproses dan merupakan unsur yang sangat fundamental dalam setiap penyelenggaraan jenis dan jenjang pendidikan. Ini berarti bahwa berhasil atau gagalnya pencapaian tujuan pendidikan itu sangat tergantung pada proses belajar yang dialami siswa. Baik ketika ia berada di sekolah maupun di lingkungan rumah atau keluarganya sendiri.

Menurut ahli pendidikan adalah suatu bentuk pertumbuhan atau perubahan dalam diri seseorang yang dinyatakan dalam cara-cara bertingkah laku yang baru dari pengalaman-pengalaman dan latihan. Para ahli pendidik modern mendefinisikan belajar adalah merupakan suatu perubahan dalam tingkah laku, belajar merupakan suatu perubahan yang terjadi melalui latihan atau pengalaman. Belajar adalah perubahan yang relatif dan mantap, belajar menyangkut aspek kepribadian, baik fisik maupun psikis, seperti perubahan dalam pengertian, pemecahan suatu masalah atau berfikir, keterampilan, kecakapan, kebiasaan ataupun sikap. Belajar adalah proses memperoleh pengetahuan, belajar suatu perubahan kemampuan bereaksi yang relatif langgeng sebagai hasil latihan yang diperkuat dan belajar adalah merupakan proses yang secara umum menetap, ada kemampuan bereaksi, adanya suatu yang diperkuat dan dilakukan dalam bentuk praktek dan latihan.

Pada hakikatnya belajar merupakan proses perubahan tingkah laku yang terjadi pada diri seseorang. Hamalik (2004) mengemukakan bahwa hasil belajar tampak sebagai terjadinya perubahan tingkah laku pada diri siswa yang dapat diamati dan diukur dalam bentuk perubahan pengetahuan, sikap dan keterampilan. 
Perubahan tersebut dapat diartikan terjadinya peningkatan dan pengembangan yang lebih baik dibandingkan dengan sebelumnya, misalnya dari kurang tahu menjadi tahu, sikap kurang sopan menjadi sopan, dan sebagainya. Selain itu Arikunto (2006) mengemukakan pula bahwa hasil belajar merupakan hasil yang diperoleh siswa setelah melakukan kegiatan belajar dan merupakan penilaian yang dicapai siswa untuk mengetahui sejauh mana materi yang diajarkan dapat diterima oleh siswa.

Selanjutnya, perangkat pembelajaran adalah seperangkat administrasi pengajaran yang disusun oleh peneliti sebelum proses pembelajaran dimulai baik dalam jangka pendek, maupun jangka panjang (satu tahun dan satu semester). Mulyasa (2006) membagi perangkat pembelajaran menjadi program tahunan, program semester, silabus, dan rencana pelaksanaan pembelajaran (RPP). Program tahunan menurut Mulyasa merupakan program umum setiap mata pelajaran untuk setiap kelas, yang dikembangkan oleh peneliti mata pelajaran yang bersangkutan. Program ini perlu dipersiapkan dan dikembangkan oleh peneliti sebelum tahun ajaran, karena merupakan pedoman bagi pengembangan program-program berikutnya, yakni program semester, RPP dan lain-lain. Program semester menurutnya berisikan garis-garis besar mengenai hal-hal yang hendak dilaksanakan dan dicapai dalam semester tersebut. Program ini merupakan penjabaran dari program tahunan.

Pada umumnya program semester ini berisikan tentang bulan, pokok bahasan yang hendak disampaikan, waktu yang direncanakan dan keteranganketerangan lain. Silabus merupakan acuan pengembangan RPP yang memuat identitas mata pelajaran, standar kompetensi (SK), kompetensi dasar (KD), materi pembelajaran, kegiatan pembelajaran, indikator pencapaian kompetensi, penilaian, alokasi waktu, dan sumber belajar. Pada dasarnya silabus merupakan uraian yang lebih rinci mengenai kompetensi dasar, materi standar dan hasil belajar yang harus dimiliki oleh siswa sehubungan dengan suatu mata pelajaran (Mulyasa, 2006).

Rencana pelaksanaan pembelajaran (RPP) merupakan perencanaan pendek tentang apa yang akan dilakukan peneliti saat pembelajaran. RPP dijabarkan dari silabus untuk mencapai tujuan pembelajaran. Setiap peneliti berkewajiban menyusun RPP dengan lengkap dan sistematis agar pembelajaran berlangsung interaktif, inspiratif, menyenangkan, menantang, memotivasi siswa untuk berpartisipasi aktif, serta memberikan kesempatan yang cukup bagi kreatifitas, kemandirian, bakat, minat, dan perkembangan fisik serta psikologis siswa. RPP merupakan upaya untuk memperkirakan tindakan yang akan dilakukan dalam kegiatan pembelajaran (Mulyasa, 2006).

\section{Mata Pelajaran Ekonomi}

Seiring dengan perkembangan jaman dan ilmu pengetahuan muncullah ilmu yang disebut ilmu ekonomi. Menurut Paul A. Samuelson (dalam Sukwiaty, 2009) mengemukakan bahwa ilmu ekonomi sebagai suatu studi tentang perilaku orang dan masyarakat dalam memilih cara menggunakan sumber daya yang langka dan memiliki beberapa alternatif penggunaan, dalam rangka memproduksi berbagai komoditas, untuk kemudian menyalurkannya, baik saat ini maupun di masa depan kepada berbagai individu dan kelompok yang ada dalam suatu 
masyarakat. Berdasarkan uraian di atas maka dapat disimpulkan bahwa mata pelajaran ekonomi adalah bagian dari mata pelajaran di sekolah yang mempelajari perilaku individu dan masyarakat dalam usaha memenuhi kebutuhan hidupnya yang tak terbatas dengan alat pemuas kebutuhan yang terbatas jumlahnya.

Tujuan Pembelajaran Ekonomi adalah dalam proses pembelajaran terlebih dahulu harus menentukan tujuan yang ingin dicapai dan merumuskan kemampuan apa yang harus dimiliki oleh siswa setelah mengikuti kegiatan pembelajaran. Pengertian tujuan pembelajaran antara lain dikemukakan oleh Nana Sudjana (2003) yang menjelaskan bahwa tujuan pembelajaran adalah rumusan pernyataan mengenai kemampuan atau tingkah laku yang diharapkan dimiliki atau dikuasai siswa setelah siswa menerima proses pengajaran. Sedangkan menurut Wina Sanjaya (2006) tujuan pembelajaran adalah kemampuan yang harus dimiliki oleh anak didik setelah mereka mempelajari bahasan tertentu dalam satu kali pertemuan.

Berdasarkan uraian tersebut dapat disimpulkan bahwa tujuan pembelajaran adalah kemampuan (kompetensi) atau keterampilan yang diharapkan dapat dimiliki oleh siswa setelah mereka mempelajari bahasan tertentu dalam setiap kali pembelajaran berakhir. Karena hanya peneliti yang mengetahui karakteristik siswa dan karakteristik materi pelajaran yang diajarkan, maka yang bertugas merumuskan tujuan pembelajaran adalah guru.

Komponen-komponen yang harus diperhatikan dalam rumusan indikator tujuan belajar adalah siapa yang diharapkan mencapai tujuan atau hasil belajar itu, tingkah laku apa yang diharapkan dapat dicapai, dalam kondisi yang bagaimana kondisi belajar dapat ditampilkan. Dalam sistem pendidikan nasional rumusan tujuan pendidikan, baik tujuan kurikuler maupun tujuan instruksional (pembelajaran), menggunakan klasifikasi hasil belajar dari Benyamin Bloom yang secara garis besar membaginya menjadi tiga ranah, yaitu ranah kognitif (kemampuan intelektual), ranah afektif (sikap), dan psikomotorik atau keterampilan (Nana Sudjana, 2003).

Sebuah proses pembelajaran yang baik hendaknya tidak hanya mengacu pada tujuan/hasil belajar sampai pada domain kognitif saja, sebaiknya harus menunjukan keseimbangan antara tiga aspek yaitu kognitif, afektif, dan psikomotorik. Karena hakikatnya, tujuan pembelajaran adalah sebagai arah dari proses belajar mengajar yang diharapkan mampu mewujudkan rumusan tingkah laku yang dapat dikuasai siswa setelah siswa menempuh pengalaman belajarnya.

Mata pelajaran ekonomi bertujuan agar siswa memiliki kemampuan sebagai berikut:

1) Memenuhi sejumlah konsep ekonomi yang berkaitan peristiwa dan masalah ekonomi dengan kehidupan sehari-hari. Terutama yang terjadi di lingkungan individu, rumah tangga, masyarakat dan negara.

2) Menampilkan sikap ingin tahu dan terhadap sejumlah konsep ekonomi yang diperlukan untuk mendalami ilmu ekonomi.

3) Membentuk sikap bijak, rasional, dan bertanggung jawab dengan memiliki pengetahuan dan keterampilan ilmu ekonomi, manajemen, dan akuntansi yang bermanfaat bagi diri sendiri, rumah tangga, masyarakat dan negara. 
4) Membuat keputusan yang bertanggung jawab mengenai nilai-nilai sosial ekonomi dalam masyarakat yang majemuk, baik dalam skala nasional maupun internasional (Sumber: Permendiknas No. 22 Tahun 2006 tentang Standar Isi untuk Satuan Pendidikan Dasar dan Menengah).

Berdasarkan penjelasan di atas dapat disimpulkan bahwa mata pelajaran ekonomi bukanlah mata pelajaran yang bersifat hafalan, sehingga siswa harus diajarkan untuk berekonomi dengan mengenal berbagai kenyataan dan peristiwa ekonomi yang terjadi secara nyata maka pembelajaran ekonomi perlu menggunakan metode pembelajaran yang kreatif dan inovatif sesuai dengan apa yang dibutuhkan oleh siswa serta disesuaikan dengan kondisi agar tujuan pembelajaran dapat tercapai.

\section{Metode Eksporitori}

Salah satu metode pembelajaran yang sering digunakan peneliti adalah metode eksporitori. Metode eksporitori yang dekat (mirip atau segolongan dengan metode ceramah, direct instruction, atau pembelajaran langsung). Secara definisi, metode eksporitori adalah suatu metode yang menggunakan cara penyampaian pelajaran dari seorang peneliti kepada siswa di dalam kelas dengan: (1) berbicara di awal pelajaran; (2) menerangkan materi dan contoh soal disertai tanya jawab. Menurut Wina Sanjaya (2006) metode pembelajaran eksporitori adalah metode pembelajaran yang menekankan kepada proses penyampaian materi secara verbal dari seorang peneliti kepada sekelompok siswa dengan maksud agar siswa dapat menguasai materi pelajaran secara optimal. Sanjaya menamakan strategi ini dengan istilah metode pembelajaran secara langsung (direct instruction). Karena dalam strategi ini materi pelajaran disampaikan langsung oleh peneliti.

Menurut Sagala (2010) pendekatan eksporitori bertolak dari pandangan, bahwa tingkah laku kelas dan penyebab pengetahuan dikontrol dan ditentukan oleh peneliti/pengajar. Hakekat mengajar menurut pandangan ini adalah menyampaikan ilmu pengetahuan kepada siswa. Siswa dipandang sebagai objek yang menerima apa yang diberikan peneliti. Biasanya peneliti menyampaikan informasi mengenai bahan pengajaran dalam bentuk penjelasan dan penuturan secara lisan, yang dikenal dengan istilah, kuliah, ceramah, dan lecture. Dalam pendekatan ini peneliti siswa diharapkan dapat menangkap dan mengingat informasi yang telah diberikan peneliti, serta mengungkapkan kembali apa yang dimilikinya melalui respon yang ia berikan pada saat diberikan pertanyaan oleh peneliti.

Metode pembelajaran eksporitori adalah strategi pembelajaran yang menekankan kepada proses penyampaian materi secara verbal dari seorang peneliti kepada sekelompok siswa dengan maksud agar siswa dapat menguasai materi pelajaran secara optimal. Terdapat beberapa karakteristik metode eksporitori. Pertama, metode eksporitori dilakukan dengan cara menyampaikan materi pelajaran secara verbal, artinya bertutur secara lisan merupakan alat utama dalam melakukan strategi ini, oleh karena itu sering orang mengidentikanya dengan ceramah. Kedua, biasanya materi pelajaran yang disampaikan adalah materi pelajaran yang sudah jadi, seperti data atau fakta, konsep-konsep tertentu yang harus dihafal sehingga tidak menuntut siswa untuk berpikir ulang. Ketiga, 
tujuan utama pembelajaran adalah penguasaan materi pelajaran itu sendiri, artinya, setelah proses pembelajaran berakhir siswa diharapkan dapat memahaminya dengan benar dengan cara dapat mengungkapkan kembali materi yang telah diuraikan.

Metode pembelajaran eksporitori merupakan bentuk dari pendekatan pembelajaran yang beriorentasi kepada peneliti (teacher centered approach). Dikatakan demikian, sebab dalam strategi ini peneliti memegang peran yang sangat dominan. Melalui strategi ini peneliti menyampaikan materi pembelajaran secara testruktur dengan harapan materi pelajaran yang disampaikan itu dapat dikuasai siswa dengan baik. Strategi pembelajaran akan efektif manakala:

a. Peneliti akan menyampaikan bahan-bahan baru serta kaitanya dengan yang akan dan baru dipelajari siswa (overview). Biasanya bahan atau materi itu diperlukan untuk kegiatan-kegiatan khusus, seperti kegiatan pemecahan masalah atau untuk melakukan proses tertentu. Oleh sebab itu, materi yang disampaikan adalah materi-materi dasar seperti konsep-konsep tertentu, prosedur, atau rangkaian aktivitas, dan lain sebagainya.

b. Apabila peneliti mengiginkan agar siswa mempunyai gaya model intelektual tertentu, misalnya agar siswa bisa mengingat bahan pelajarn sehingga ia akan dapat mengungkapkan kembali manakala diperlukan.

c. Jika bahan pelajaran yang akan diajarkan cocok untuk dipresentasikan, artinya dipandang dari sifat dan jenis materi pelajaran memang materi pelajaran itu hanya mungkin dapat dipahami oleh siswa manakala disampaikan oleh peneliti, misalnya materi pelajaran dari hasil penelitian berupa data-data khusus.

d. Jika ingin membangkitkan keingintahuan siswa tentang topik tertentu. Misalnya, materi pelajaran yang bersifat pancingan untuk meningkatkan motivasi belajar siswa.

e. Peneliti mengiginkan untuk mendemonstrasikan suatu teknik atau prosedur tertentu untuk kegiatan praktik. Prosedur biasanya merupakan langkah baku atau langkah standar yang harus ditaati dalam melakukan suatu proses tertentu. Manakala langkah itu tidak ditaati, maka dapat menimbulkan pengaruh atau resiko tertentu.

f. Apabila seluruh siswa memiliki tingkat kesulitan yang sama sehingga peneliti perlu menjelaskan untuk seluruh siswa.

g. Apabila peneliti akan mengajar pada sekelompok siswa yang rata-rata memiliki kemampuan rendah.

h. Jika lingkungan tidak mendukung untuk menggunakan strategi yang berpusat pada siswa, misalnya tidak adanya sarana dan prasarana yang dibutuhkan.

i. Jika peneliti tidak memiliki waktu yang cukup untuk menggunakan pendekatan yang berpusat pada siswa.

\section{Hasil Belajar}

Hasil belajar adalah kemampuan-kemampuan yang dimiliki siswa setelah ia menerima pengalaman belajarnya. Dalam sistem pendidikan nasional rumusan tujuan pendidikan, baik tujuan kurikuler maupun tujuan tujuan instruksional, 
menggunakan klsifikasi hasil belajar dari Benyamin Bloom yang secara garis besar membaginya menjadi tiga ranah yakni:

1. Ranah kognitif, berkenaan dengan dengan hasil belajar intelektual yang terdiri dari enam aspek, yakni pengetahuan atau ingatan, pemahaman, aplikasi, analisis, sintesis, dan evaluasi.

2. Ranah afektif berkenaan dengan sikap yang terdiri dari lima aspek, yakni penerimaan, jawaban atau reaksi, penilaian, organisasi, dan internalisasi.

3. Ranah psikomotorik berkenaan dengan hasil belajar ketrampilan dan kemampuan bertindak.

Ketiga ranah tersebut menjadi penilaian hasil belajar. Di antara ketiga ranah itu, ranah kognitiflah yang paling danyak dinilai oleh para peneliti disekolah karena berkaitan dengan kemampuan para siswa dalam menguasai isi pengajaran (Nana Sudjana, 2003).

Menurut Slameto (2003) ada dua faktor utama yang mempengaruhi hasil belajar siswa, yaitu :

1. Faktor dari dalam siswa: faktor jasmaniah (faktor kesehatan dan cacat tubuh), faktor psikologis (intelegensi, perhatian, minat, bakat, motif, kematangan, kesiapan), dan faktor kelelahan.

2. Faktor dari luar siswa: faktor keluarga (cara orang tua mendidik, relasi antar anggota keluarga, suasana rumah, keadaan ekonomi keluarga, pengertian orang tua, dan latar belakang kebudayaan), faktor sekolah (metode mengajar, kurikulum, relasi peneliti dengan siswa, relasi siswa dengan siswa, disiplin sekolah, alat pengajaran, waktu sekolah, standar pelajaran di atas ukuran, keadaan gedung, tugas rumah, metode belajar), faktor masyarakat (kegiatan siswa dalam masyarakat, mass media, teman bergaul, dan bentuk kehidupan masyarakat).

Hasil belajar mata pelajaran ekonomi mencakup kecakapan akademik, kesadaran ekonomi dan nasionalisme (Aman, 2011). Kecakapan akademik menyangkut ranah kognitif yang mengacu pada standar kompetensi dan kompetensi dasar yang dikembangkan dalam pembelajaran yang bersumber dari kurikulum uang berlaku. Penilaian kesadaran ekonomi tersebut menurut Aman meliputi kemampuan:

1) menghayati makna dan hakekat ekonomi bagi masa kini dan masa yang akan datang

2) mengenal diri sendiri dan bangsannya;

3) membudayakan ekonomi bagi pembinaan budaya bangsa

4) menjaga peninggalan ekonomi bangsa.

Sedangkan aspek nasionalisme menyangkut kemampuan:

1) perasaan bangga siswa sebagai bangsa Indonesia;

2) rasa cinta tanah air dan bangsa;

3) rela berkorban demi bangsa

4) menerima kemajemukan

5) bangga pada budaya yang beraneka ragam;

6) menghargai jasa para pahlawan; dan

7) mengutamakan kepentingan umum. 


\section{Metode Penelitian}

Penelitian ini merupakan penelitian tindakan kelas (Classroom Action Research) yang terdiri dari dua siklus. Kelas XI IPS 3 Peneliti menerapkan desain penelitian model Kemmis dan Mc Taggart. Setiap siklus terdiri dari empat langkah yaitu perencanaan, tindakan, observasi dan refleksi. Penelitian dilaksanakan di SMA Negeri 1 Koto Balingka yang beralamat di Jl. Lintas Barat, Kecamatan Koto balingka Kabupaten Pasaman Barat, Propinsi Sumatera Barat Kelas XI IPS 3. Penelitian ini dilakukan bulan Oktober 2015 selama 2 minggu.

Subyek dalam penelitian ini adalah siswa kelas XI IPS 3 semester satu tahun pelajaran 2015/2016 SMA Negeri 1 Koto Balingka Kelas XI IPS 3 berjumlah 32 siswa, terdiri dari 20 siswa perempuan dan 12 siswa laki-laki. Pengamatan dalam penelitian ini dilakukan bersamaan dengan tindakan untuk mengamati proses pembelajaran dengan menggunakan metode ekspositori. Observasi dilakukan oleh peneliti dan kolabolator. Aspek yang diobservasi adalah aktivitas siswa selama proses pembelajaran berlangsung dan prestasi belajar siswa. Data dalam penelitian ini berupa pembicaraan peneliti mitra dan siswa baik lisan maupun tertulis, gambar atau foto-foto yang memperlihatkan tindakan peneliti dan siswa dalam interaksi pembelajaran dengan menerapkan metode pembelajaran metode ekspositori, serta skor nilai belajar siswa.

Sumber data dalam penelitian ini adalah peneliti mitra (kolaborator) dan siswa kelas XI IPS 3 SMAN 1 Koto Balingka. Data yang diperoleh dalam penelitian ini dianalisis secara deskriptif kualitatif. Analisis data tentang penerapan metode ekspositori dilakukan dengan membandingkan skor ketercapaian siklus I dan siklus II. Setelah diperoleh data serta sajiannya, dilakukan penilaian keberhasilan tindakan. Penilaian keberhasilan tindakan ditentukan sesuai dengan data yang terkumpul. Data hasil penelitian penelitian kemudian ditabulasi, disimpulkan, dimaknai dan ditentukan parsentase keberhasilanya. Untuk mlihat kecendrungan data, data ditampilkan dalam bentuk tabel, grafik dan diolah secara deskriptif.

\section{Hasil Penelitian dan Pembahasan}

\section{Deskripsi Hasil Penelitian per Siklus}

Studi awal peneliti mengenai proses pembelajaran difokuskan pada aktifitas siswa terhadap pembelajaran ekonomi, dengan kriteria motivasi yaitu:

1) Berdiskusi untuk menjawab pertanyaan peneliti;

2) Menggunakan media pembelajaran untuk menyelesaikan tugas;

3) Mencatat hasil kerja kelompok;

4) Bertanya kepada peneliti atau rekan kelompok jika ada hal yang belum dipahami;

5) Melaporkan hasil kerja kelompok;

6) Mengerjakan tugas; dan

7) Berpartisipasi dalam kelompok.

Pada studi awal ini dikatakan bahwa motivasi siswa dalam pembelajaran ekonomi tentang di kelas XI IPS 3 SMA Negeri 1 Koto Balingka masih rendah. 
Hal ini antara lain disebabkan pembelajaran di kelas hanya bersifat transfer ilmu pengetahuan saja dan dilakukan secara konvensional dengan menyampaikan materi pelajaran sebanyak-banyaknya tanpa memperhatikan kebutuhan siswa. Selain itu peneliti juga belum melakukan Penelitian Tindakan Kelas (PTK).

\section{Hasil Belajar}

Hasil belajar pada studi awal pembelajaran ekonomi tentang di kelas XI IPS 3 SMA Negeri 1 Koto Balingka masih sangat rendah dan belum sesuai dengan yang diharapkan peneliti. Hal ini bisa dilihat pada Tabel 1 berikut.

Table 1 Kondisi Awal Ketuntasan Hasil Belajar Siswa dengan KKM = 76

\begin{tabular}{|c|c|c|c|c|}
\hline No & Nama Siswa & KKM & $\begin{array}{c}\text { Hasil } \\
\text { Tes }\end{array}$ & $\begin{array}{c}\text { Ketuntasan Belajar } \\
\text { (Tuntas/Tidak tuntas) }\end{array}$ \\
\hline 1 & AFRIANI & 76 & 50 & Tidak Tuntas \\
\hline 2 & AFRIO PRAMUJA & 76 & 80 & Tuntas \\
\hline 3 & AINIL FITRI & 76 & 60 & Tidak Tuntas \\
\hline 4 & AJIEZI AULIA PULUNGAN & 76 & 65 & Tidak Tuntas \\
\hline 5 & ASMIRA SOFIA & 76 & 60 & Tidak Tuntas \\
\hline 6 & BUDI IRWANTO & 76 & 80 & Tuntas \\
\hline 7 & DAHNIL AMBYA H.R & 76 & 55 & Tidak Tuntas \\
\hline 8 & ELI SARA & 76 & 45 & Tidak Tuntas \\
\hline 9 & EVA TRISIA & 76 & 80 & Tuntas \\
\hline 10 & FAUZI FANDIKO SAPUTRA & 76 & 80 & Tuntas \\
\hline 11 & FEBRI ILYAS & 76 & 80 & Tuntas \\
\hline 12 & FITRI AULIA & 76 & 55 & Tidak Tuntas \\
\hline 13 & HAIRUM PINEM & 76 & 45 & Tidak Tuntas \\
\hline 14 & IRNA DWI CAHYANTI & 76 & 65 & Tidak Tuntas \\
\hline 15 & JON REFDI & 76 & 80 & Tuntas \\
\hline 16 & JUNI YANTI & 76 & 45 & Tidak Tuntas \\
\hline 17 & JUNITA & 76 & 80 & Tuntas \\
\hline 18 & LILI FITRIANI & 76 & 45 & Tidak Tuntas \\
\hline 19 & MELIA SARI & 76 & 45 & Tidak Tuntas \\
\hline 20 & MIRA SUSANTI & 76 & 65 & Tidak Tuntas \\
\hline 21 & NAJIMAN HADI & 76 & 45 & Tidak Tuntas \\
\hline 22 & PERI KURNIAWAN & 76 & 80 & Tuntas \\
\hline 23 & PUTRI NALA & 76 & 45 & Tidak Tuntas \\
\hline 24 & RAHMAD RESKI & 76 & 85 & Tuntas \\
\hline 25 & RESI ASWITA & 76 & 45 & Tidak Tuntas \\
\hline 26 & RIMBUN PARLAUNGAN & 76 & 80 & Tuntas \\
\hline 27 & RINA FEBRIZA & 76 & 45 & Tidak Tuntas \\
\hline 28 & RIZINA AMELIA & 76 & 80 & Tuntas \\
\hline 29 & SILVIA FITRI & 76 & 55 & Tidak Tuntas \\
\hline 30 & SINTA BELA & 76 & 45 & Tidak Tuntas \\
\hline 31 & YENITA PUSPITA SARI & 76 & 45 & Tidak Tuntas \\
\hline 32 & ZAKIATUR RAHMI & 76 & 76 & Tuntas \\
\hline & Jumlah & & 1986 & \\
\hline & Rata-rata & & 62.1 & \\
\hline & Persentase & \multicolumn{3}{|c|}{$37,5 \%$ (Tuntas) } \\
\hline
\end{tabular}


Berdasarkan Tabel 1 tersebut dapat diperoleh informasi bahwa Kriteria Ketuntasan Belajar Minimal (KKM) untuk mata pelajaran ekonomi kelas XI IPS 3 SMA Negeri 1 Koto Balingka adalah 76, dari 32 siswa kelas XI IPS 3 yang mengalami ketidaktuntasan belajar sebanyak 20 siswa $(62,5 \%)$ di bawah KKM, sisanya 12 siswa telah mengalami ketuntasan belajar yaitu 37,5\% di atas KKM, dari batas tuntas yang diharapkan oleh peneliti yaitu $76 \%$. Nilai terendah yang didapatkan siswa yaitu 45 dan nilai tertinggi 80, dengan rata-rata kelas 62,1.

Dari paparan informasi di atas dapat disimpulkan bahwa hasil belajar pada studi awal masih sangat rendah, maka dari itu sebagai tindak lanjut untuk meningkatkan kualitas pembelajaran ekonomi maka peneliti melakukan Penelitian Tindakan Kelas (PTK).

\section{Siklus I}

Sebagai tindak lanjut dari proses pembelajaran dan hasil belajar studi awal yang sangat rendah, maka peneliti melakukan PTK dengan melakukan proses pembelajaran siklus I. Sesuai dengan jadwal yang ditentukan, maka dilakukan 2 kali pertemuan, dan pada pertemuan ketiga dilakukan tes siklus. Proses pembelajaran siklus I dilakukan pada tanggal 12 dan 14 oktober 2015 dan pada tanggal 15 Oktober 2015 dilakukan tes siklus I. Semua aktivitas siswa dicatat sesuai dengan format observasi yang telah disiapkan oleh peneliti. Berdasarkan hasil observasi langsung yang diperoleh melalui lembaran observasi, pengamatan yang dilakukan observer mengenai aktivitas siswa dilakukan dengan mencatat (mendata) banyak siswa yang melakukan aktivitas sesuai dengan yang terdapat pada lembaran observasi. Data hasil observasi tentang kegiatan siswa selama mengikuti proses pembelajaran dapat dilihat pada Table 2 berikut ini.

Tabel 2. Hasil Lembar Observasi Aktifitas Siswa Siklus I

\begin{tabular}{lcc}
\hline No & Pertemuan & Persentase \\
\hline 1. & I & $54,9 \%$ \\
2. & II & $65,2 \%$ \\
\hline
\end{tabular}

Keberhasilan siswa dalam belajar juga ditentukan oleh keberhasilan peneliti menyajikan materi pelajaran. Untuk mengetahui keberhasilan peneliti dalam melaksanakan pembelajaran perlu diamati oleh kolaborator. Hasil yang diperoleh adalah: pertemuan pertama $=50,0 \%$ dan pada pertemuan kedua $=64,6 \%$. Dilihat dari hasil tersebut, sudah nampak adanya kenaikan dari pertemuan 1 dan pertemuan 2, dengan persentase kenaikan sebesar 14,6\%. Dengan rata-rata persentase pertemuan 1 dan pertemuan 2 adalah 57,3\%.

Selanjutnya, hasil belajar siswa berdasarkan tes pada siklus pertama dapat pula diperhatikan pada Tabel 3 dengan hasil sebagai berikut: jumlah siswa 32 orang dengan nilai rata-rata 67,6 . Sedangkan persentase siswa yang tuntas hanya $46,8 \%$, dan $53,2 \%$ ternyata tidak tuntas. Hal tersebut membuktikan bahwa nilai mata pelajaran Ekonomi siswa masih rendah dan masih di bawah indikator 
keberhasilan yang telah ditentukan yaitu KKM yang ditargetkan adalah 76 . Sehingga langkah perbaikan pembelajaran mutlak dilakukan.

Table 3. Hasil Belajar Siswa pada Siklus I

\begin{tabular}{llc}
\hline No & \multicolumn{1}{c}{ Uraian } & Nilai siklus I \\
\hline 1. & Nilai rata-rata & 67,6 \\
2. & Persentase Tuntas & 46,8 \\
3. & Persentase Tidak Tuntas & 53,2 \\
\hline
\end{tabular}

Selanjutnya dalam penelitian ini juga digunakan angket. Angket bertujuan untuk memperoleh informasi tentang pelaksanaan metode ekspositori, memperteguh kejadian, kegiatan, kepedulian, perasaan, tuntutan tentang situasi pembelajaran, serta untuk mendapatkan data kuantitatif secara langsung dari siswa. Pada saat refleksi di akhir siklus pembelajaran diajukan beberapa pertanyaan kepada siswa baik individu maupun kelompok. Pada siklus ini, hasil angket yang dari siswa yang menjawan "Ya" adalah 52,2\%, sedangkan sebesar 47,8\% siswa menjawab "Tidak". Artinya pada siklus ini belum mencapai hasil yang maksimal.

\section{Siklus II}

Siklus II dilaksanakan sebagai tindak lanjut dari proses pembelajaran dan hasil belajar pada siklus I yang belum optimal. Siklus II dilaksanakan 2 kali pertemuan pada tanggal 19 dan 21 Oktober 2015, dan pada pertemuan ketiga tanggal 22 Oktober 2015 dilakukan tes siklus II. Peneliti membagi siswa dalam kelompok kecil dengan jumlah 3 atau 4 siswa dalam satu kelompok. Peneliti menjelaskan sekilas materi kemudian membagikan lembar kerja siswa (LKS). Peneliti memberikan petunjuk dalam mengerjakan LKS.

Pada siklus II ini siswa telah terlihat percaya diri. Hal ini dimungkinkan siswa telah terbiasa dalam mempresentasikan hasil diskusi di depan kelas. Setelah selesai mempresentasikan hasil diskusi, peneliti memberikan penguatan konsep, memberikan soal evaluasi, dan membahas soal evaluasi bersama serta menyimpulkan materi pembelajaran. Berdasarkan pengamatan observasi pada siklus kedua tentang aktivitas siswa adalah sebagai berikut:

Tabel 4. hasil lembar observasi aktifitas siswa siklus II

\begin{tabular}{lcc}
\hline No & Pertemuan & Persentase \\
\hline 1 & I & $74,2 \%$ \\
2 & II & $87,5 \%$ \\
\hline & Rata-rata & $80,9 \%$ \\
\hline
\end{tabular}

Dari Tabel 4 di atas terlihat bahwa aktifitas siswa sudah mulai nampak, dan peningkatan yang sudah besar dibandingkan dengan siklus I. Peningkatan pada siklus II ini terjadi dengan nilai persentase rata-rata sebesar $80,9 \%$, sedangkan 
persentase rata-rata siklus I adalah 60,1. Ini berarti meningkat dari siklus I ke siklus II sebesar 20,8\%.

Sedangkan ketuntasan hasil belajar siswa pada siklus kedua adalah sebagai berikut: dari 32 orang siswa yang tuntas (yang bernilai $\geq$ KKM ) adalah 27 orang dengan parsentase ketuntasan $84,4 \%$, dan siswa yang tidak tuntas adalah 7 orang $(15,6 \%)$. Sedangkan pada siklus I, dari 32 orang siswa, mereka yang tuntas (yang bernilai $\geq \mathrm{KKM}$ ) adalah 15 orang dengan parsentase ketuntasan 46,8\%. Berarti pada siklus kedua jumlah siswa yang tuntas meningkat 12 orang dengan parsentase peningkatan sebesar $37,6 \%$. Selanjutnya gambaran hasil belajar siswa di siklus II dapat pula dilihat pada Tabel 5 berikut ini.

Tabel 5. Hasil Belajar Siswa pada Siklus II

\begin{tabular}{llc}
\hline No & \multicolumn{1}{c}{ Uraian } & Nilai siklus II \\
\hline 1. & Nilai rata-rata & 82,6 \\
2. & Persentase Tuntas & 84,4 \\
3. & Persentase Tidak Tuntas & 15,6 \\
\hline
\end{tabular}

Selain itu pada siklus II juga diedarkan angket kepada siswa. Angket bertujuan untuk memperoleh informasi tentang pelaksanaan metode ekspositori, memperteguh kejadian, kegiatan, kepedulian, perasaan, tuntutan tentang situasi pembelajaran, serta untuk mendapatkan data kuantitatif secara langsung dari siswa yang dilakukan ketika refleksi di akhir siklus pembelajaran. Dalam angket ini diajukan beberapa pertanyaan kepada siswa baik individu maupun kelompok. Hasil angket yang diperoleh pada siklus II dari siswa menunjukkan bahwa siswa yang menjawab "Ya" adalah $80 \%$. Sedangkan sebesar $20 \%$ siswa yang menjawab "Tidak". Artinya sudah meningkat pada hasil siklus I.

\section{Pembahasan Hasil Penelitian}

Proses pembelajaran dalam penelitian ini mengalami peningkatan bila dibandingkan dengan studi awal pembelajaran dengan siklus I dan siklus II. Proses pembelajaran pada studi awal aktivitas siswa siswa belum muncul. Hal ini disebabkan pembelajaran masih konvensional. Penyampaian informasi hanya dengan metode ceramah saja dan belum dilaksanakannya pengelolaan kelas yaitu dengan metode ekspositori, sehingga aktivitas siswa belum terlihat.

Proses pembelajaran pada siklus I dan siklus II aktivitas siswa mulai terlihat dan motivasi siswa dalam proses pembelajaran juga meningkat. Hal ini disebabkan sudah adanya perubahan metode pembelajaran dan pengelolaan kelas dengan baik. Peneliti tidak hanya menyampaikan pembelajaran secara ceramah saja, namun sudah menggunakan metode ekspositori yaitu dengan kelompok besar yang beranggotakan 5 atau 6 siswa tiap kelompok. Dalam proses pembelajaran tersebut peneliti juga telah memberikan bimbingan kepada siswa yang mengalami kesulitan-kesulitan dalam metode ekspositori. 
Metode ekspositori merupakan konsep belajar yang membantu peneliti mengaitkan antara materi yang diajarkan dengan situasi dunia nyata siswa dan mendorong siswa membuat hubungan antara pengetahuan yang dimilikinya dengan penerapannya dalam kehidupan mereka sebagai anggota keluarga dan masyarakat. Dalam konteks ini siswa akan menyadari bahwa apa yang mereka pelajari berguna bagi hidupnya nanti, sehingga akan membuat mereka memposisikan diri sebagai diri sendiri yang memerlukan suatu bekal yang bermanfaat untuk hidupnya nanti dan siswa akan berusaha untuk menggapainya. Dengan menerapkan metode ini maka aktivitas pembelajaran lebih bermakna dan meningkat, siswa lebih aktif dan kreatif serta memiliki motivasi belajar yang lebih baik lagi.

Peningkatan aktivitas siswa dalam pembelajaran siklus I memang telah mengalami peningkatan, namun peningkatan tersebut menurut peneliti belumlah optimal, sehingga peneliti melanjutkan PTK dalam siklus II. Hasil belajar siswa pada siklus I dan siklus II telah meningkat dibandingkan pada studi awal pembelajaran. Hal ini bisa dilihat pada Tabel perbandingan berikut ini.

Tabel 6. Perbandingan Hasil Belajar Siswa Siklus I dan Siklus II

\begin{tabular}{lllll}
\hline No. & Uraian & $\begin{array}{l}\text { Kondisi } \\
\text { Awal }\end{array}$ & $\begin{array}{l}\text { Nilai } \\
\text { siklus I }\end{array}$ & $\begin{array}{l}\text { Nilai } \\
\text { siklus II }\end{array}$ \\
\hline 1. & Nilai rata-rata & 62,1 & 67,5 & 82,6 \\
2. & Persentase (Tuntas) & 37,5 & 46,8 & 84,4 \\
3. & Persentase (Tidak Tuntas) & 62,5 & 53,2 & 15,6 \\
\hline
\end{tabular}

Dari Tabel 6 tersebut dapat diperoleh informasi bahwa hasil belajar siswa pada siklus I dan siklus II mengalami peningkatan dibandingkan hasil belajar siswa pada studi awal. Jika pada studi awal ketuntasan belajar siswa secara klasikal hanya $37,5 \%$ atau siswa yang tuntas belajar sebanyak 12 dari 32 siswa, sehingga 20 siswa lainnya belum tuntas belajar atau 62,5\%. Sedangkan pada siklus I sebanyak 15 dari 32 siswa telah tuntas belajar atau $46,8 \%$ dan siswa yang belum tuntas belajar sebanyak 17 siswa atau $53,2 \%$. Selanjutnya pada siklus II siswa yang tuntas sebanyak 27 siswa atau $84,4 \%$ dan sebanyak 5 siswa yang belum tuntas atau $15,6 \%$.

Peningkatan hasil belajar pada siklus I dan siklus II ini dipacu oleh perubahan pola pembelajaran yang semula hanya bersifat konvensional atau transfer pengetahuan saja, beralih kepada metode ekspositori yang juga melibatkan aktifitas siswa dalam proses pembelajaran yang lebih bermakna yaitu dengan bekerja kelompok dengan anggota kelompok 5 atau 6 siswa setiap kelompok. Hasil belajar pada suklus I tersebut dirasakan oleh peneliti belumlah optimal, sehingga peneliti melanjutkan lagi pada pembelajaran siklus II.

Pelaksanaan pembelajaran siklus I sesuai dengan apa yang telah direncanakan pada siklus I. Pembelajaran disajikan dalam 3 kali pertemuan. Dalam suatu kegiatan pembelajaran siswa dikatakan telah belajar, apabila terjadi proses perubahan perilaku pada diri siswa. Pelaksanaan proses pembelajaran pada 
siklus I belum sempurna. Hal ini dapat dilihat dari dua aspek, pertama dari aktivitas siswa selama proses pembelajaran berlangsung belum maksimal, siswa belum semua terlihat aktif dalam proses pembelajaran. Berdasarkan lembar aktivitas dari aspek siswa secara keseluruhan pada siklus I dan siklus II dapat dilihat dalam Tabel 7 berikut.

Tabel 7. Data Perbandingan Aktivitas Siswa Pada Siklus 1 dengan Siklus 2

\begin{tabular}{lcc}
\hline \multicolumn{1}{c}{ Siklus } & Pertemuan I & Pertemuan II \\
\hline Siklus I & 54,9 & 65,2 \\
Siklus II & 74,2 & 87,5 \\
\hline
\end{tabular}

Berdasarkan Tabel 7 di atas, terlihat bahwa parsentase aktivitas siswa pada pertemuan I dan pertemuan II pada siklus I meningkat 10,3\%. Sedangkan pada siklus II pada pertemuan I dan pertemuan II meningkat 13,3\%. Peningkatan aktivitas siswa yang mengerjakan pekerjaan rumah merupakan hasil yang diperolehnya waktu di sekolah. Secara keseluruhan aktivitas belajar siswa pada siklus pertama secara signifikan meningkat. Hal itu disebabkan karena pada siklus kedua peneliti lebih mendorong peningkatan aktivitas belajar peserta dengan menyampaikan bahwa aktivitas yang dilakukannya akan berpengaruh dalam memperoleh nilai akhirnya. Aktivitas yang terjadi pada sikulus I mengalami peningkatan pada siklus II.

Dalam penelitian ini guru berusaha memperbaiki kekurangankekurangannya dalam melaksanakan pembelajaran, cara mengajukan pertanyaan, memberi motivasi, menyajikan materi mengaplikasikan materi, pemberian tugas dan membimbing siswa dalam menarik kesimpulan sesuai dengan maksud dari penggunaan metode ekspositori dalam pembelajaran. Wina Sanjaya (2006) menjelaskan bahwa metode pembelajaran eksporitori adalah metode pembelajaran yang menekankan kepada proses penyampaian materi secara verbal dari seorang peneliti kepada sekelompok siswa dengan maksud agar siswa dapat menguasai materi pelajaran secara optimal. Dalam kaitan ini Guru (Peneliti) telah berusaha memotivasi siswa dalam melaksanakan pembelajaran dengan menantang siswa dengan tanya jawab baik tanya jawab yang berasal dari Guru maupun dari teman sendiri.

Peneliti juga berusaha agar pembelajaran terlaksana sehingga siswa aktif, menyenangkan dan menatang sehingga tujuan pembelajaran dapat tercapai secara maksimal karena penyampaian materi telah diusahakan severbal mungkin kepada siswa sehingga siswa terlihat menjadi lebih aktif. Proses pembelajaran dikatakan optimal apabila keaktifan siswa dan hasil belajar siswa yang tinggi. Pada penelitian ini juga sudah kelihatan peningkatan hasil belajar siswa, yang berarti bahwa peneliti telah berhasil dalam melaksanakan pembelajaran, keberhasilan tersebut diketahui setelah diadakan evaluasi dengan seperangkat item soal.

\section{Penutup}

Metode ekspositori sangat efektif dalam memepengaruhi hasil belajar siswa kelas XI IPS 3 SMA Negeri 1 Koto Balingka dalam mata pelajaran ekonomi. Metode 
ekspositori efektif dalam mempengaruhi terhadap ketuntasan belajar siswa kelas XI IPS 3 SMA Negeri 1 Koto Balingka dalam mata pelajaran ekonomi. Hal ini disebabkan metode pembelajaran yang digunakan dalam metode ekspositori cukup menantang bagi siswa sehingga sangat diminati.

Metode ekspositori memfokuskan kepada peneliti perlu memberitahu pelajaran yang berkaitan tentang perkembangan teknologi. Siswa belajar mengenai bahan yang disampaikan oleh peneliti. Kemudian siswa akan bekerja mengikut lembaran kerja yang disampaikan oleh peneliti untuk menguasai konsep. Berdasarkan hasil penelitian tindakan kelas ini terbukti dan dapat disimpulkan bahwa penggunaan metode pembelajaran ekspositori dalam mata pelajaran Ekonomi ternyata dapat meningkatkan hasil belajar siswa di SMAN 1 Koto Balingka Pasaman Barat.

Berdasarkan hasil dan kesimpulan penelitian ini maka beberapa saran dapat disampaikan dalam hasil penelitian ini sebagai berikut:

1. Peneliti mata pelajaran ekonomi hendaknya mampu dan mau menggunakan metode pembelajaran pembelajaran yang menarik siswa. Metode ekspositori terbukti dapat meningkatkan KKM dan kemampuan berdiskusi siswa. Selain itu, metode pembelajaran pembelajaran tersebut dapat dirasakan menyenangkan siswa.

2. Metode ekspositori perlu dihgunakan sebagai metode pembelajaran utama dalam pelajaran ekonomi karena memiliki keunggulan merangsang daya pikir, kemampuan berargumen, dan keaktifan siswa.

3. Para peneliti yang mengajar ekonomi kiranya dapat melakukan penelitian lanjutan mengenai pembelajaran kooperatif. Para peneliti dapat menerapkan berbagai strategi, metode pembelajaran, metode, teknik, dan media berdasarkan metode tertentu yang tepat untuk meningkatkan keaktifan siswa. Hasil penelitian tersebut diharapkan dapat membantu peneliti untuk memecahkan masalah yang sering muncul dalam proses pelajaran ekonomi di kelas sehingga berdampak positif bagi perkembangan pendidikan yang lebih berkualitas

\section{DAFTAR KEPUSTAKAAN}

Aman. (2011). Model Evaluasi Pembelajaran Sejarah. Yogyakarta: Ombak.

Arikunto, Suharsimi. (2006). Penelitian Tindakan Kelas. Jakarta: Bumi Aksara.

Hamalik, Oemar. (2004). Proses Belajar Mengajar. Jakarta: Bumi Aksara.

Mulyasa. (2006). Kurikulum yang Disempurnakan. Bandung: PT. Remaja Rosdakarya.

Nana, Sudjana. (2003). Cara Belajar Siswa Aktif dalam Proses Belajar Mengajar. Bandung: Sinar Baru.

Permendiknas No. 22 Tahun 2006 tentang Standar Isi untuk Satuan Pendidikan Dasar dan Menengah. 
Sagala, Syaiful. (2010). Konsep dan Makna Pembelajaran . Bandung: Alfabeta.

Sanjaya, Wina. (2006). Strategi Pembelajaran Berorientasi Standar Proses Pendidikan. Jakarta: Kencana Prenada Media Group.

Slameto. (2003). Belajar dan Faktor-faktor yang Mempengaruhinya. Jakarta: Rineka Cipta.

Sukwiaty. (2009). Ekonomi SMA untuk Kelas X. Jakarta: Yudistira. 